\title{
Dialectics of Gender and Reproductive Health
}

\begin{abstract}
The relationship between gender and health is a deeply interdependent one. Yet research in this area has focused primarily on how gender relations determine health behavior and health outcomes. This article advocates a more holistic approach that conceptualizes gender and health as fully intertwined and mutually constitutive. This interplay is explored through the case of HIV discordance in which one person in a relationship is HIV positive and the other HIV negative. Drawing on in-depth research with discordant couples in urban Uganda, this study indicates that living with discordance can both reinforce and challenge normative gender power dynamics in relationships. This study, therefore, illustrates how significant health problems can influence gender relations. As such, it reveals the dialectical relationship between gender and health and also provides important insights for HIV prevention in the new era of antiretroviral treatment as prevention.
\end{abstract}

Sijapati Dipendra Bikram, M. Phil

Key word: Dialectics of Gender, Reproductive Health, Sexual Health and Sexual Right

\section{Introduction}

Basically, the gender dichotomy must be healed and sealed; people must be free to develop their own unique identity. In philosophy, the method, or method research orientation most often and most efficiently used to overcome ("transcend") dualism is dialectics. Chris Sciabarra has suggested this definition of dialectics: Dialectics is a methodological-research orientation whose distinguishing characteristic is an emphasis on conceptuality in the analysis of systemic and dynamic relations within totalities (i.e., organic unities). Thus, dialectics is a way to consider the issue in question both structurally and dynamically, as a whole, but changing and developing system, a way of exploring the developments and shifting relationships of a great many interacting factors, never losing track of the whole context of the system - always considering the full context, both analyzing the parts themselves and considering their relative place to each other and within the totality. Which is exactly what needs to be done with the splintered, arbitrary chaos of the gender concepts? Gender inclusion to the participation and role of decision making and change her social and economic behavior. Attaining the goals of sustainable, equitable development requires that people are able to exercise control over their sexual and reproductive lives. Sexual and reproductive rights are a cornerstone of development. The neglect of sexual and reproductive health and rights lies at the root of many of the problems the international community has identified in need of urgent action, including violence, sexual abuse and 
rape of women and children; HIV/AIDS; maternal mortality; teenage pregnancy; abandoned children; harmful practices such as female genital mutilation; population growth; the juvenisation and feminization of poverty; and the violation of fundamental human rights and human dignity, including of the basic rights to security and liberty of the person. The ICPD Programme of Action and the Beijing Platform for Action recognize sexual and reproductive rights as human rights thereby affirming them as an inalienable, integral and indivisible part of universal human rights.

\section{Objectives}

* To find out concepts gender inclusion to the participation and role of decision making and change her social and Reproductive Health behavior.

* To advocate a holistic approach that conceptualizes gender and health as fully intertwined and mutually constitutive.

\section{Methods}

This paper based on secondary sources of data of Nepal Demographic and Health Survey NDHS -2011 and 2016. The other related published Reproductive health and gender inclusion related; policies, acts and programmes, books, research journals and different reports are basically used. The raw data are analysed using the statistical package of social science (SPSS) program on computer and calculated in frequency distribution and percentage to make its meaningful analysis. Data are carefully analysed and to interpret for generalization.

\section{Results}

Unwanted fertility and maternal care in Nepal

The total wanted fertility rate in Nepal, as a whole is 2.5 births per woman, 1.6 births less than the actual total fertility rate 4.1. This implies that the total fertility rate is about 64 per cent higher than it would be if unwanted births were avoided. The difference between wanted and actual total fertility rates is larger among rural than urban women and among women from the mountains than from the hills and Terai. Among the five development regions, the difference between wanted and actual total fertility rates is highest in midwestern region (2.1), followed by Far-Western (1.8), Central (1.6), Eastern (1.5) and Western (1.3). The difference is also bigger among women with no education than among those with some secondary education and SLC+. 
Patan Pragya (Volume: 6, Number: 1 2020)

Table:1 Total wanted fertility rates and total fertility rates for the three years preceding the survey by selected background characteristics, Nepal 2001

\begin{tabular}{|l|c|c|c|}
\hline $\begin{array}{l}\text { Background } \\
\text { characteristics }\end{array}$ & $\begin{array}{l}\text { Total wanted } \\
\text { fertility rate }\end{array}$ & $\begin{array}{l}\text { Total fertility } \\
\text { rate }\end{array}$ & Difference \\
\hline Place of residence & & & \\
\hline Urban & 1.4 & 2.1 & 0.7 \\
\hline Rural & 2.6 & 4.4 & 1.8 \\
\hline Ecological region & & & 2.2 \\
\hline Mountain & 2.6 & 4.8 & 1.7 \\
\hline Hill & 2.3 & 4.0 & 1.5 \\
\hline Terai & 2.6 & 4.1 & \\
\hline Development & & & 1.5 \\
Region & & & 1.6 \\
\hline Eastern & 2.3 & 3.8 & 1.3 \\
\hline Central & 2.7 & 4.3 & 2.1 \\
\hline Western & 2.2 & 3.5 & 1.8 \\
\hline Mid western & 2.6 & 4.7 & 1.8 \\
\hline Far western & 2.9 & 4.7 & 1.2 \\
\hline Education & & & 0.7 \\
\hline No education & 3.0 & 4.8 & 0.3 \\
\hline Primary & 2.0 & 3.2 & $\mathbf{1 . 6}$ \\
\hline Some secondary & 1.6 & 2.3 & \\
\hline SLC+ & 1.8 & 2.1 & $\mathbf{4 . 1}$ \\
\hline Nepal & $\mathbf{2 . 5}$ & & \\
\hline Sour & & & \\
\hline
\end{tabular}

Source: MoH, New ERA and ORC Macro, 2014

The extent of the physical hazards of unwanted pregnancies depends largely on two factors: the accessibility of efficient maternity services to deal with complications of pregnancy and child birth and the accessibility of safe pregnancy termination services

Table: 2 Maternal care in Nepal by background characteristics, Nepal, 2001

\begin{tabular}{|l|c|c|c|c|}
\hline & \multicolumn{2}{|c|}{ \% of births to mothers who received } & \multicolumn{2}{c|}{$\begin{array}{c}\text { \% of births to mothers } \\
\text { assisted at delivery by }\end{array}$} \\
\hline $\begin{array}{l}\text { Background } \\
\text { characteristic }\end{array}$ & $\begin{array}{c}\text { no antenatal } \\
\text { care }\end{array}$ & $\begin{array}{c}\text { two or more TT } \\
\text { injection during } \\
\text { pregnancy }\end{array}$ & $\begin{array}{c}\text { Doctor/nur } \\
\text { se/ } \\
\text { mid } \\
\text { wife }\end{array}$ & TBA \\
\hline $\begin{array}{l}\text { Place of } \\
\text { Residence }\end{array}$ & & & & \\
\hline Urban & 17.6 & 67.3 & 50.3 & 9.4 \\
\hline
\end{tabular}


Patan Pragya (Volume: 6, Number: 1 2020)

\begin{tabular}{|l|c|c|c|c|}
\hline Rural & 53.4 & 43.7 & 8.1 & 24.4 \\
\hline Ecological region & & & & \\
\hline Mountain & 69.3 & 21.3 & 4.0 & 10.1 \\
\hline Hill & 56.0 & 34.9 & 10.9 & 7.0 \\
\hline Terai & 43.9 & 57.4 & 11.8 & 38.6 \\
\hline $\begin{array}{l}\text { Development } \\
\text { region }\end{array}$ & & & \\
\hline Eastern & 45.7 & 53.6 & 13.3 & 25.6 \\
\hline Central & 47.4 & 50.1 & 12.9 & 29.2 \\
\hline Western & 43.5 & 34.3 & 11.6 & 17.8 \\
\hline Mid-western & 64.9 & 29.9 & 4.1 & 19.4 \\
\hline Far-western & 67.0 & & 7.7 & 15.8 \\
\hline Education & & 39.0 & & \\
\hline No education & 60.8 & 52.8 & 5.2 & 25.6 \\
\hline Primary & 35.5 & 67.7 & 14.1 & 19.4 \\
\hline Some secondary & 16.0 & 81.1 & 33.1 & 16.3 \\
\hline SLC+ & 5.2 & $\mathbf{4 5 . 3}$ & 64.1 & 9.9 \\
\hline Nepal & $\mathbf{5 0 . 9}$ & $\mathbf{1 0 . 9}$ & $\mathbf{2 3 . 4}$ \\
\hline
\end{tabular}

Source: MoH, New ERA and ORC Macro, 2014.

According to WHO, UNICEF and UNFPA estimate (2003), the MMR for the world is 400 and it is 20 for the developed regions, and 440 for developing regions. Although maternal deaths are almost rare events in industrialized countries, they are still a major cause of death for women of childbearing age in developing countries. In many developing countries, maternal deaths account for 25-33 percent of all deaths of women of childbearing age. It is estimated that 585,000 women in developing countries die every year as a result of pregnancy and child birth (UNFPA, 1999). Thus every minute of every day, a woman dies due to complications of pregnancy and childbirth and many more suffer illness or disability.

\section{Limiting births to the healthiest ages.}

Child bearing is safer for women between the ages of 20 and 40. The health risks of childbearing increase after age 40. Among women ages 40-44, for example, the risk of death is five times higher than among women in their 20s (Upadhyay and Robey, 1999: 8). Pregnancy before 20 carries many health risks. However, it is found that there is one in every six births in least developed countries is to teenage mothers aged 15-19. It is quite natural that adolescent mothers will have more children than those who start childbearing later. It is found that women ages 15-19 are twice as likely to die from childbirth and those under age 15 are five times as likely to die as compared to women in their 20s (UN, 1991). 
Patan Pragya (Volume: 6, Number: 1 2020)

Table: 3 Percentage of women ages 15-19 who are mothers or pregnant with their first child, by selected background characteristics, Nepal 2001

\begin{tabular}{|l|c|}
\hline Background characteristics & \% who are mothers or pregnant with first child \\
\hline Place of residence & 12.6 \\
\hline Urban & 22.5 \\
\hline Rural & \\
\hline Ecological region & 19.7 \\
\hline Mountain & 17.0 \\
\hline Hill & 25.6 \\
\hline Terai & \\
\hline Development region & 22.6 \\
\hline Eastern & 23.8 \\
\hline Central & 16.1 \\
\hline Western & 22.0 \\
\hline Mid-western & 22.5 \\
\hline Far-western & \\
\hline Education & 31.5 \\
\hline No education & 19.6 \\
\hline Primary & 13.2 \\
\hline Some secondary & 8.3 \\
\hline SLC+ & $\mathbf{2 1 . 4}$ \\
\hline Nepal & \\
\hline Solit & \\
\hline
\end{tabular}

Source: MoH,New ERA and ORC Macro, 2014

One in five women ages 15-19 is already a mother or pregnant with her first child, with teenage childbearing more common in Nepal. Adolescent pregnancy is common due to lack of information and services.

*Also examine for background characteristics.

In Nepal, adolescent childbearing is common. Three out of 10 young women had their first child before the age of 18 (Pradhan et al., 1997).

\section{Limiting the number of births}

Family planning helps women avoid giving birth more times than is good for their health. Women who give birth four times or more face dramatically higher maternal health risks. The recommended message is have few children (less than four) or stop at one or two regardless of sex. In Nepal, whether we consider TFR (4.1) or Mean number of children ever born (MNOC) to women ages 40-49 which is 5.4 (MOH, New ERA and ORC Macro, 2002), both indicate exceeding the recommended births. 
Thus the role of family planning program is quite important in saving women's lives, if we consider the points discussed above. The ineffective family planning program unnecessarily increases maternal mortality.

\section{Efforts, Challenges and Opportunities}

- Creating a common ground - major rationales for the organized RH and FP program effort

- Meeting unmet need for family planning

- Expanding access and quality of RH and FP services - make sure FP/RH services reach the poor/deprived group.

- Saving women's lives.

- Quality contraceptives and choice (i.e. access to RH care including a range of FP information and services. "Access with quality".

- Addressing issues of adolescent sexual reproductive behavior.

- Involving men

- Effective reproductive health service delivery including family planning.

The preceding discussion clearly shows with evidences that the role of family planning is quite important in saving women's lives. Since the ineffective family planning program unnecessarily increases maternal mortality, it therefore calls for an effective or organized family planning program effort to avoid unwanted pregnancies and thereby saving women's lives.

Efforts should be made in creating a common ground so far as the health and human right rationales for the organized family planning program are concerned.

Saving women's lives also calls for expanding access and quality of family planning services. It is to make sure that family planning and reproductive health services especially safe motherhood services reach the deprived group. Emphasis should be on the access to safe motherhood services with quality of care.

Finally, there is a need for effective RH/FP services to increase the coverage of maternal health care. Service delivery efforts should pay attention to Government commitment, financial commitment of the Government, the quality of program organization and management, efforts to generate demand for and accessibility to quality reproductive health and family planning services. 
Patan Pragya (Volume: 6, Number: 1 2020)

Table: 4 Indicators of our Women (Demography and RH) INDICATORS

\begin{tabular}{|c|c|c|c|c|c|c|c|c|}
\hline $\begin{array}{l}\text { Indicators of our } \\
\text { Women (Demography } \\
\text { and RH)INDICATORS }\end{array}$ & LDCs & $\begin{array}{l}\mathrm{B} \\
\mathrm{N} \\
\mathrm{G} \\
\mathrm{L} \\
\mathrm{A} \\
\mathrm{D} \\
\mathrm{E} \\
\mathrm{S} \\
\mathrm{H}\end{array}$ & $\begin{array}{l}\mathrm{B} \\
\mathrm{H} \\
\mathrm{U} \\
\mathrm{T} \\
\mathrm{A} \\
\mathrm{N}\end{array}$ & $\begin{array}{c}\mathrm{I} \\
\mathrm{N} \\
\mathrm{D} \\
\mathrm{I} \\
\mathrm{A}\end{array}$ & $\begin{array}{c}\text { M } \\
\text { A } \\
\text { L } \\
\text { D } \\
\text { I } \\
\text { V } \\
\text { E } \\
\text { S }\end{array}$ & $\begin{array}{l}\mathrm{N} \\
\mathrm{E} \\
\mathrm{P} \\
\mathrm{A} \\
\mathrm{L}\end{array}$ & $\begin{array}{c}\mathrm{P} \\
\mathrm{A} \\
\mathrm{K} \\
\mathrm{I} \\
\mathrm{S} \\
\mathrm{T} \\
\mathrm{A} \\
\mathrm{N}\end{array}$ & $\begin{array}{l}\mathrm{S} \\
\mathrm{R} \\
\mathrm{I} \\
\mathrm{L} \\
\mathrm{A} \\
\mathrm{N} \\
\mathrm{K} \\
\mathrm{A}\end{array}$ \\
\hline $\begin{array}{lcc}\text { Total } & \text { Females (in } \\
\text { millions) } 2005\end{array}$ & 2,587 & $\begin{array}{c}74 . \\
4\end{array}$ & 1.2 & 531.9 & 0.2 & 12.9 & $\begin{array}{c}78 . \\
7\end{array}$ & 9.4 \\
\hline $\begin{array}{l}\% \text { of } \\
\text { women in } \\
\text { ages }(2005) \\
<1515-49>50\end{array}$ & $\begin{array}{l}31 \\
53 \\
17\end{array}$ & $\begin{array}{l}37 \\
52 \\
11\end{array}$ & $\begin{array}{l}40 \\
47 \\
13\end{array}$ & $\begin{array}{l}32 \\
52 \\
16\end{array}$ & $\begin{array}{l}42 \\
48 \\
10\end{array}$ & $\begin{array}{l}39 \\
48 \\
13\end{array}$ & $\begin{array}{l}40 \\
48 \\
12\end{array}$ & $\begin{array}{l}24 \\
56 \\
20\end{array}$ \\
\hline $\begin{array}{l}\text { Lifetime Births } \\
\text { women (TFR) }\end{array}$ & 3.0 & 3.0 & 4.7 & 3.1 & 3.7 & 4.1 & 4.8 & 2.0 \\
\hline $\begin{array}{l}\text { \% of } \\
\text { women ages } 15-19 \\
\text { giving birth in one year }\end{array}$ & 7 & 11 & 5 & 11 & 5 & 11 & 7 & 2 \\
\hline $\begin{array}{lr}\text { Percentage of } & \text { married } \\
\text { women } & \text { using } \\
\text { contraception } & \\
\text { Any method } & \\
\text { Modern } & \\
\end{array}$ & $\begin{array}{l}57 \\
51 \\
\end{array}$ & $\begin{array}{l}54 \\
43 \\
\end{array}$ & $\begin{array}{c}- \\
31 \\
\end{array}$ & $\begin{array}{l}48 \\
43 \\
\end{array}$ & $\begin{array}{l}42 \\
32 \\
\end{array}$ & $\begin{array}{l}39 \\
35 \\
\end{array}$ & $\begin{array}{l}28 \\
20 \\
\end{array}$ & $\begin{array}{l}66 \\
44 \\
\end{array}$ \\
\hline $\begin{array}{lll}\begin{array}{l}\text { Percent } \\
\text { attended }\end{array} & \text { of } & \text { Births } \\
\text { personnel } & \text { by } & \text { skilled } \\
\end{array}$ & 57 & 13 & 15 & 43 & - & 11 & 20 & 94 \\
\hline $\begin{array}{l}\text { Maternal deaths per } \\
100,000 \text { live births, } \\
2000\end{array}$ & 440 & 380 & $\begin{array}{c}42 \\
0\end{array}$ & 540 & 110 & 740 & $\begin{array}{c}50 \\
0 \\
\end{array}$ & 92 \\
\hline $\begin{array}{l}\text { Lifetime chance of } \\
\text { dying from maternal } \\
\text { causes, } 1 \text { in }\end{array}$ & 61 & 59 & 37 & 48 & 140 & 24 & 31 & 430 \\
\hline Abortion policy, 2004 & - & * & * & $* * * *$ & $* * *$ & $* * * *$ & $\begin{array}{c}* * \\
*\end{array}$ & $*$ \\
\hline $\begin{array}{l}\text { \% of adults } \\
\text { age 15-49 } \\
\text { with } \\
(2003 / 04)\end{array}$ & 1.4 & - & - & 0.9 & - & 0.5 & 0.1 & $\mathrm{Z}$ \\
\hline
\end{tabular}


Patan Pragya (Volume: 6, Number: 1 2020)

\begin{tabular}{|l|l|l|l|l|l|l|l|l|}
\hline $\begin{array}{l}\text { \% of HIV-Infected } \\
\text { adults who are women } \\
(2003 / 04)\end{array}$ & 51 & 15 & - & 37 & - & 27 & 12 & 17 \\
\hline
\end{tabular}

Source: Women of Our World, 2015

\section{Conclusion}

Sexual Health aims at the enhancement of life and personal relations, and sexual health services should not consist merely of counseling and care related to reproduction and sexually transmitted diseases.

Reproductive Health is a state of complete physical, mental and social well-being and not merely the absence of disease or infirmity, in all matters related to the reproductive system and to its functions and processes. People are able to have a satisfying and safe sex life and they have the capability to reproduce and the freedom to decide if, when and how often to do so. Men and women have the right to be informed and to have access to safe, effective, affordable and acceptable methods of their choice for the regulation of fertility which are not against the law, as well as the right of access to health care for safe pregnancy and childbirth. Reproductive health care is defined as the constellation of methods, techniques and services that contribute to reproductive health and well-being by preventing and solving reproductive health problems. Sexual Rights include the human right of women to have control over and decide freely and responsibly on matters related to their sexuality, including sexual and reproductive health, free of coercion, discrimination and violence. Reproductive Rights embrace certain human rights recognized in national and international legal and human rights documents, including the basic right of all couples and individuals to decide feely and responsibly the number and spacing of their children, and to have the right to attain the highest standard of sexual and reproductive health; the right to make decisions concerning reproduction free of discrimination, coercion and violence.

\section{References:}

CREHPA, n.d. Unsafe Abortions Have Adverse Social and Health Implications, Facts and Figures.

Ministry of Health, 1998, National Reproductive Health Strategy (Kathmandu: FHD, DoH, $\mathrm{MoH})$.

Ministry of Health, 1998, Safe Motherhood Policy (Kathmandu: FHD, DOH, MOH). Ministry of Health, 2005, Annual Report, DOHS, (2003/04) 2060/61 (Kathmandu: MOH). Ministry of Health, New ERA \& ORC Macro 2002, Nepal Demographic and Health Survey 2001, (Calverton, Maryland, USA: FHD, MOH; New ERA; and ORC Macro).

National Planning Commission (NPC), 2002, The Tenth Plan, 2002-2007 (Kathmandu: NPC). 
Pathak Ram Sharan 1997, "The Quality of Family Planning Services in Nepal: An Assessment", Nepal Population Journal, Population Association of Nepal (PAN), Kathmandu, Vol. 6, No.5, 1997.

Pathak, Ram Sharan, 1996, Government Family Planning Programme Efforts in Nepal: An Evaluation, An Unpublished Ph.D. Thesis (Canberra: The ANU).

Pathak, Ram Sharan, 2000, "Ready Accessibility to Contraceptives in Nepal”, Population and Development in Nepal, Vol.7 (Kathmandu: CDPS).

Population Reference Bureau (PRB), 2005, Women of Our World (New York: PRB).

Pradhan, A., R.H. Aryal, G. Regmi, B. Ban and P. Govindasamy, 1997, Nepal Family Health Survey, 1996 (Kathmandu, Nepal and Calverton, Maryland: Ministry of Health [Nepal], New Era, and Macro International inc.).

United Nations Population Fund (UNFPA), 1997, The State of World Population, The Right to Choose: The Reproductive Right and Reproductive Health (New York: UNFPA).

United Nations Population Fund (UNFPA), 1999, The State of World Population, 6 Billion, A Time for Choices (New York: UNFPA).

United Nations Population Fund (UNFPA), 2004, The State of World Population, The Cairo Consensus at Ten: Population, Reproductive Health and the Global Effort to End Poverty (New York: UNFPA).

United Nations, 1994, International Conference on Population and Development, (New York: United Nations).

Upadhyay, U.D., and Robey, B., 1999, “Why Family Planning Matters”, Population Reports, (an ICPD+5 Issues) Series J, No.49 (Baltimore: JHU, School of Public Health, Population Information Program).

WHO and UNICEF, 1996, Revised 1990 Estimates of Maternal Mortality: A New Approach by WHO and UNICEF (Geneva: WHO). 